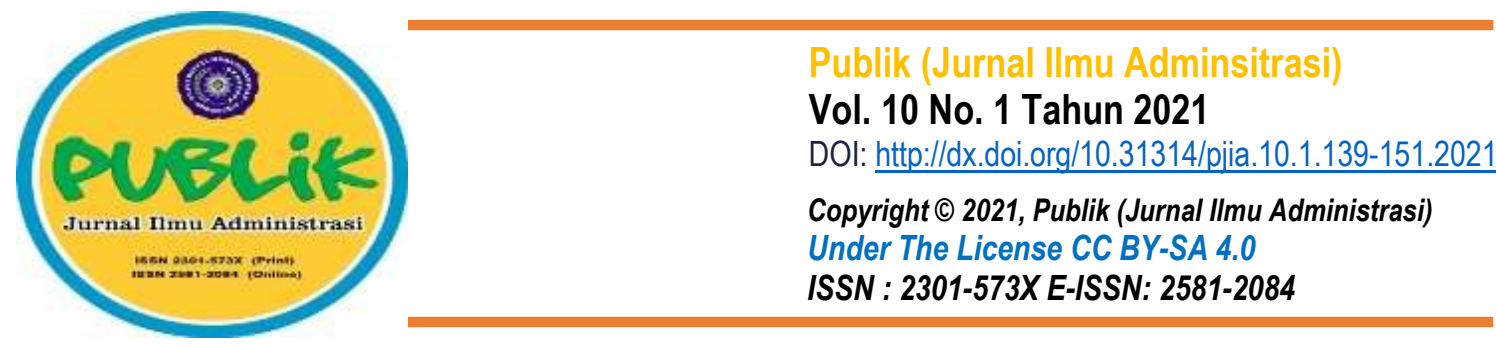

\title{
Implementation of The Local Budget Social Assistance Policy for Disability in Tangerang Selatan
}

Lisa Amilia1 Retnowati WD Tuti2 ${ }^{*}$

$1,2^{*}$ Master of Administrative Sciences, Faculty of Social and Political Sciences, University of Muhammadiyah Jakarta; amilia.sos141@gmail.com , retnowiwdtuti@yahoo.com

Abstract. Social assistance is one of the poverty reduction programs carried out by the South Tangerang City Government. Poverty is defined as a condition of the inability of income to meet basic needs so that it is not able to guarantee survival. South Tangerang City has received the spill over effect of various economic impacts. Persons with disabilities have a low level of welfare. The low welfare is partly because they have limited physical functions and often have negative emotional experiences due to their physical limitations. Limited physical functions make it difficult for persons with disabilities to access work because they are considered less productive. This has a negative impact on persons with disabilities such as losing their role, independence, status, and financial stability. The purpose of this study is to analyze the implementation of regional budget social assistance policies for disabilities in South Tangerang. And to find out the supporting factors and inhibiting factors. This research method uses a qualitative approach with descriptive methods. qualitative approach, using the Theory of Policy Implementation according to Edward III. The results of this study indicate that the implementation of the Regional Budget Social Assistance Policy for Disabilities in South Tangerang has not been going well, it is based on poor communication from the implementor to the community, in terms of both human and financial resources are still lacking. Likewise, the supporting facilities in implementing social assistance for disabilities. And most importantly.

Keywords: Implementation; Policy; Social Assistance; Disability

\section{Received:21-11-2020 Revised:28-05-2021 Accepted:03-06-2021}

\section{INTRODUCTION}

People with disabilities have a low level of welfare. The low level of well-being is partly because they have limited physical function and often have negative emotional experiences due to their physical limitations. Limitations of physical function make it difficult for people with disabilities to access work because they are considered less productive. This has a negative impact on people with disabilities such as losing their role, independence, status, and financial stability.

Social Assistance is one of the poverty reduction programs carried out by the South Tangerang City Government. Poverty is defined as the inability of income to meet basic needs so that it is less able to ensure survival. South Tangerang City received a spill over effect of various economic, social, spatial and environmental impacts. One of the indications of the spill effect is the 
continued increase in population, both as a result of population migration from rural to urban areas and migration from urban centers to suburbs (sub-urbanization). The process of population migration, not all experience an increase in the welfare of life, when the migrating population cannot keep up with the development of the capital city world, then it will still be backward and will only add to the list of Persons with Social Welfare Problems (PMKS), as well as PMKS in South Tangerang. The number of PMKS in 2018 was 9,200. The number is increasing and demanding the local government to find a solution in reducing the poverty level in South Tangerang City and ensuring an increase in the social welfare of the PMKS. One way is to provide stimulant assistance to the poor, institutions/foundations and organizations in need. Stimulant assistance provided by the Regional Government can be in the form of Social Assistance in Goods, Money, which is given to Foundations and individuals which is legalized in South Tangerang Mayor Regulation Number 26 of 2018 concerning Guidelines for the Management of Grants and Social Assistance sourced from the Regional Budget. as well as PMKS in South Tangerang.

The number of PMKS in 2018 was 9,200. The number is increasing and demanding the local government to find a solution in reducing the poverty level in South Tangerang City and ensuring an increase in the social welfare of the PMKS. One way is to provide stimulant assistance to the poor, institutions/foundations and organizations in need. Stimulant assistance provided by the Regional Government can be in the form of Social Assistance in Goods, Money, which is given to Foundations and individuals which is legalized in South Tangerang Mayor Regulation Number 26 of 2018 concerning Guidelines for the Management of Grants and Social Assistance sourced from the Regional Budget. as well as PMKS in South Tangerang. The number of PMKS in 2018 was 9,200 . The number is increasing and demanding the local government to find a solution in reducing the poverty level in South Tangerang City and ensuring an increase in the social welfare of the PMKS. One way is to provide stimulant assistance to the poor, institutions/foundations and organizations in need. Stimulant assistance provided by the Regional Government can be in the form of Social Assistance in Goods, Money, which is given to Foundations and individuals which is legalized in South Tangerang Mayor Regulation Number 26 of 2018 concerning Guidelines for the Management of Grants and Social Assistance sourced from the Regional Budget. The number is increasing and demanding the local government to find a solution in reducing the poverty level in South Tangerang City and ensuring an increase in the social welfare of the PMKS. One way is to provide stimulant assistance to the poor, institutions/foundations and organizations in need. Stimulant assistance provided by the Regional Government can be in the form of Social Assistance in Goods, Money, which is given to Foundations and individuals which is legalized in South 
Tangerang Mayor Regulation Number 26 of 2018 concerning Guidelines for the Management of Grants and Social Assistance sourced from the Regional Budget. The number is increasing and demanding the local government to find solutions to reduce poverty in South Tangerang City and ensure the improvement of the social welfare of the PMKS. One way is to provide stimulant assistance to the poor, institutions/foundations and organizations in need. Stimulant assistance provided by the Regional Government can be in the form of Social Assistance in Goods, Money, which is given to Foundations and individuals which is legalized in South Tangerang Mayor Regulation Number 26 of 2018 concerning Guidelines for the Management of Grants and Social Assistance sourced from the Regional Budget. One way is to provide stimulant assistance to the poor, institutions/foundations and organizations in need. Stimulant assistance provided by the Regional Government can be in the form of Social Assistance in Goods, Money, which is given to Foundations and individuals which is legalized in South Tangerang Mayor Regulation Number 26 of 2018 concerning Guidelines for the Management of Grants and Social Assistance sourced from the Regional Budget. One way is to provide stimulant assistance to the poor, institutions/foundations and organizations in need. Stimulant assistance provided by the Regional Government can be in the form of Social Assistance in Goods, Money, which is given to Foundations and individuals which is legalized in South Tangerang Mayor Regulation Number 26 of 2018 concerning Guidelines for the Management of Grants and Social Assistance sourced from the Regional Budget.(Regulation of the Mayor of South Tangerang No.26 of 2018 concerning Guidelines for the Management of Grants and Social Assistance Sourced from the Regional Budget, nd). This social assistance expenditure comes from the South Tangerang City Regional Revenue and Expenditure Budget (APBD) account. There are complaints from some people with disabilities (out of 307 people) that the process of disbursing aid is very long and some are even not disbursed, resulting in people with disabilities having less confidence in the local government; on the basis of these problems arise Quriosity Researchers conducted in-depth research conducted.

The following are some previous studies from several studies on the implementation of social assistance policies. The First Research Title Implementation of Social Assistance Distribution Policy in the National Unity Agency and City Politics. The results of this study conclude that the implementation of the Policy on the Distribution of Social Assistance at the National Unity and Political Agency of Bontang City is in accordance with existing regulations and is running as it should. However, there are still shortcomings in carrying out the budgeting process, implementing verification of social assistance and in providing recommendations. The implementation of budget 
policies that change frequently due to the intervention of the legislature results in the implementation of verification of proposals and the provision of recommendations that are not in accordance with the goals and objectives that have been set.(Trisnawati, 2016)

The second research is entitled Implementation of Village Fund Policy and Community Participation in Development in Teteaji Village, Tellu Limpoe District, Sidenreng Rappang Regency. The results of this study conclude that: 1 . Implementation of the Village fund policy with a value of $69.78 \%$ in the good category. 2. Community participation with a value of $68.4 \%$ in this study is in the good category. 3. Village development with a value of $71.4 \%$ in this study is in the good category.(Mustanir, 2016)

The third research is entitled Implementation of Management Policy at the Regional Financial and Asset Management Agency of Central Sulawesi Province. The results of this study conclude that the Implementation of Management Policy at the Regional Financial and Asset Management Agency of Central Sulawesi Province has not been effective, which according to the results of research conducted in general, the indicators of policy implementation studied include Communication, Resources, Disposition/Attitude and Bureaucratic Structure. The sub-indicators in each indicator are implemented effectively.(Febtiasari, 2017)

Fourth Research Title, Giving Based on Governor of Bali Regulation Number 2 of 2017 concerning Guidelines for Providing Social Assistance. By Ira Damayanti. The purpose of this research is to find a way out in resolving conflicts of norms in existing regulations, as well as to provide legal certainty. The normative legal research method is used in this study, using a qualitative approach. The results of the study show that the basis for regulating the implementation of grants to the Bali Provincial Government based on the Gubernatorial Social Assistance Regulation is based on the Minister of Home Affairs No. 14 of 2016, then revealed in the form of the Governor of Bali No. 2 of 2017 by applying the logical flow of giving to community organizations that are not registered with the ministry, supporting the existence of and the development of Balinese culture. The form of inconsistency in the regulation of the implementation of grants to local governments with the Law on Community Organizations. Journal of Notary Law.(Damayanti, 2018)

Fifth Research Title, Implementation of Village Fund Allocation (ADD) Policy in Balansiku Village, Sebatik District, Nunukan Regency, by Sanusi, DB Paranoan. The purpose of the study was to describe and analyze the implementation of Village Fund Allocation management in Balansiku village, Sebatik sub-district, Nunukan district. In this study used a qualitative approach with a descriptive method. The results showed that the Management of Village Fund Allocations in Balansiku Village, Sebatik Subdistrict turned out to have implications in encouraging changes or 
improvements in village development. Although the implementation of the management of village fund allocations at the research site has not been effective, it has shown significant changes to the welfare of the community. Although in the process faced with administrative problems,(Paranoan \& Djumlani, 2017)

From the five previous studies above, the theory used is different from this research which uses the Policy Implementation Theory according to Edward III. Meanwhile, previous research used Policy Implementation Theory according to Merilee S. Grindle. Therefore, there will be differences in research results. This is where the State of the Art or Novelty lies.

According to (Edwards, 1980), there are four variables that strongly support success, which consist of:

1.Communication, where a program will only run effectively if there is good communication between the implementers of resources, dispositions, and bureaucratic structures.

2.Resources, although the contents of the policy have been communicated clearly and consistently, if the implementer lacks the resources to implement it, then the implementation will not run effectively, then good implementer competencies and supporting financial resources are needed.

3.Disposition, is the character and characteristics possessed by the implementer, such as commitment, honesty, and others.

4.Bureaucratic Structure, an efficient organizational structure and a simple bureaucracy are needed. There is a division of labor and there is clarity on how the different functions or activities are integrated or coordinated. The aspect of this organizational structure is the Standard Operating Procedure (SOP) as a reference for effective and efficient organizational activities.

According to (Van Meter \& Van Horn, 1975). Indicator variables that affect the implementation of public policies are as follows:

1.Inter-organizational communication and activity strengthening.

2.Characteristics of implementing agents/competitors.

3.Economic, social, and political conditions.

4. Tendency from implementers or competitors.

5.Policy size and objectives.

6. Resource.

The implementation of the policy is considered to depend on the outcome of the program, whether it is difficult to separate the fate of the policy and its constituents.(Nicholson-Crotty \& Carley, 2016; Vonk Noordegraaf, Annema, \& van Wee, 2014) 
Implementation is a continuum between the central government and local governments.(Fischer, Miller, \& Sydney, 2007) According to Edward III, policy implementation is a crucial process because how good a policy is if it is not well prepared and planned for its implementation, then what is the goal of public policy will not be realized. According to (Pülzl \& Treib, 2017) (Verdugo et al., 2017) (Robichau \& Lynn, 2009) (Rossouw \& Wiseman, 2004) Implementation is the most important stage because during policy implementation, major problems often arise that limit policy. . Meanwhile, according to (Sætren \& Hupe, 2017) (Gauthier \& Moran, 2018) (Ansell et al., 2017) Policy implementation must use a values-based approach that establishes and defines core values and principles that guide its implementation. The purpose of this study was to analyze the implementation of the Regional Budget Social Assistance Policy for Disabilities in South Tangerang. And to know the supporting factors and inhibiting factors.

\section{METHODS}

This research method uses a qualitative approach with a descriptive method. Qualitative approach provides flexibility to view social phenomena holistically. While the descriptive method focuses on the meaning (events, processes, and themes) in depth, which is then described in the form of words and pictures.(Miles \& Huberman, 2009) A qualitative approach with a descriptive method was chosen because this study wanted to describe in detail and interpret the data obtained to explain the implementation of the Regional Budget Social Assistance Policy for Disabilities in South Tangerang. (Creswell, 2014)

The data used in this study came from various primary data obtained from in-depth interviews and Focus Group Discussions (FGD). These data were then analyzed using Policy Implementation Theory according to Edward III. With key informants, namely the South Tangerang City BPKAD, the section for assisting stimulant assistance and environmental management, and the section for social rehabilitation for people with disabilities.

\section{RESULTS AND DISCUSSION}

Based on the background of the problem and the research objectives to be achieved, namely analyzing the implementation of the Regional Budget Social Assistance policy for Disabilities in South Tangerang, the following are the results of research conducted using an analytical knife from Edward III which consists of the following 4 indicators: 


\section{Aspect of Communication (communication)}

That the communication developed between the official in charge of social assistance and the prospective beneficiaries is quite good. Communication is usually often disrupted this is due to semantic / word meaning problems, lack of feedback, communication channels, physical disturbances, cultural and status differences. There are guidelines for effective communication, including that one must listen actively, try to give feedback, go straight to the problem, describe the situation, and summarize. The communication process allows managers to carry out their responsibilities and information must be communicated to managers as a basis for making decisions in the making of managers' functions both orally and in writing.

Communication can be defined as the process of transferring ideas or information from one person to another. Besides being said to be a process of transferring one's ideas from others in the form of words, but also in the form of facial expressions, intonation and so on. Communication can link between different parts or is called a chain of information exchange. It contains elements;

1. As one's activity to understand,

2. As a means of controlling information,

3. As a system for the establishment of communication between individuals.

Based on the results of interviews with key informants and observations. Transmission: the distribution of communication in the implementation of budget social assistance for the disabled did not go well, because the communication only occurred in one direction, namely in the form of providing direction or information from the Regional Apparatus that regulates the financial management of social assistance in this case. BPKAD to the Social Service as the leading sector of social affairs, and forwarded to all prospective recipients of social assistance, including persons with disabilities. Clarity: communication received from policy implementers is unclear and confusing for persons with disabilities. The information obtained is also less transparent and clear; Consistency: in terms of consistency, the government is still often changing in giving orders. Changes in regulations as the legal basis for providing social assistance are one of the inhibiting factors for people with disabilities to complete the required requirements. This results in less effective communication, so that the implementation of social assistance for persons with disabilities using the South Tangerang regional budget is less than optimal.

\section{Aspects of Resources (resources)}

Resources are positioned as inputs in the organization as a system that has economic and technological implications. Economically, resources relate to direct costs or sacrifices incurred by 
the organization that reflect the value or potential use in their transformation into outputs. While technologically, resources are related to the transformational ability of the organization.

The data on persons with disabilities owned by the South Tangerang City Social Service is quite good, but it is deemed necessary to update the data more regularly. Because there are several names listed have died, or are no longer in South Tangerang. In order to follow up the process of implementing social assistance, especially for persons with disabilities, officials and implementers at the Social Service have maximally carried out a personal approach to persons with disabilities. This is because because of their limited accessibility, Staff: With the South Tangerang regional budget, in terms of the availability of various resources, the composition of human resources that specifically handle social assistance at the Social Service is still lacking. There are only 3 implementers and 1 Section Head who is tasked with carrying out the entire series of social assistance processes from the process of receiving proposals from the community to the disbursement process to BPKAD.

In the event that the available Dinas budget is insufficient, to carry out the social assistance management process. The budget ceiling contained in the Stimulant Assistance and Environmental Management Assistance Section is only limited to the implementation of routine activities. There is no special allocation for managing social assistance. In the Social Rehabilitation Section for Persons with Disabilities, there is no budget to collect data on persons with disabilities in South Tangerang. This resulted in less than optimal implementation of social assistance at the Department of Social Affairs. So far, the South Tangerang City Social Service has been more passive in waiting for proposals from the community to come in, submitting social assistance proposals, after which the Office will only follow up the process of social assistance proposals to the Regional Financial and Asset Management Agency.

Regarding the budget for social assistance, it is centered on the Regional Financial and Asset Management Agency, the amount of the budget set is global or there is a ceiling that is specifically allocated for planned social assistance. Although the amount of the budget for the disbursement of social assistance is in the BPKAD, the lack of budget for the Social Service in managing social assistance has resulted in the limited authority of the Social Service.

Referring to South Tangerang Mayor Regulation Number 5 of 2019 article 52 it is stated that: "social assistance in the form of money is included in the RKA-PPKD" meaning that the budget for social assistance proposed from each Regional Apparatus is fully attached to the South Tangerang City BPKAD. Regional apparatuses are only proposing names of potential recipients of social assistance. The results of the determination of candidates for receiving social assistance are 
determined by the Decree of the Mayor of South Tangerang; Information: information related to social assistance for people with disabilities is also not going well, not much information is provided by the implementer to people with disabilities. Facilities: Facilities and infrastructure that ideally support prospective recipients of social assistance, especially in this case Persons with Disabilities, are also deemed inadequate. From the results of the research, the obstacles felt by people with disabilities are in terms of their limited accessibility when they have to attend invitations and socialization repeatedly.

\section{Aspects of Attitude (disposition)}

Tendencies or dispositions are one of the factors that have important consequences for effective policy implementation. If the implementers have a positive tendency or attitude or support for the implementation of the policy, there is a high probability that the implementation of the policy will be carried out in accordance with the initial decision. On the other hand, if the implementers have a negative attitude or refuse to implement the policy because of a conflict of interest, the implementation of the policy will face serious obstacles.

Based on the results of interviews with key informants and researchers' observations regarding the implementation of social assistance for persons with disabilities in South Tangerang, in terms of the attitude aspect, all officers, both officials and implementers at the Social Service, especially those in charge of social assistance, fully support the implementation of the social assistance policy. Implementers who are in charge of the entire process of implementing social assistance get a good appreciation from the leadership of the organization. All proposals for requests for social assistance from persons with disabilities are processed in accordance with applicable regulations, and are followed up if there is an order or correction from BPKAD for revision.

The appreciation given by the leadership at BPKAD is a career pattern that will be guaranteed in the future. Because being the treasurer of this social assistance is quite a difficult task, it is not easy to manage the social assistance budget, because you must really be able to work carefully and be able to account for even a percent of the budget that has been spent.

4. Aspects of Bureaucratic / Organizational Structure (bureacratic structure)

Bureaucracy is one of the most frequent institutions, even as a whole, is the implementer of activities. The existence of bureaucracy is not only in government structures, but also in private organizations, educational institutions and so on. Even in certain cases the bureaucracy was created only to carry out a certain policy. 
Based on the results of interviews with key informants and researchers' observations from the aspect of bureaucratic/organizational structure, the role of leaders/officials in the process of social assistance originating from is very important, and carried out in stages according to the organizational structure. The division of tasks between one official and another is clear according to their duties and functions, including between officials and implementers in particular in charge of social assistance at the Social Service. However, what is still unfortunate is that there is no specific Standard Operating Procedure regarding the flow of the social assistance process at the Social Service. This resulted in the prospective social assistance proposers not being able to obtain definite information regarding the flow/process of social assistance originating from the South Tangerang City regional budget.

The mayor can determine the list of recipients of social assistance and the amount of money with a Mayor's Decree based on the Regional Regulation on APBD and Mayor Regulation on the Elaboration of APBD. The list of beneficiaries will become the basis for the distribution or delivery of social assistance in the future. The provision of social assistance in the form of money is carried out using a direct payment mechanism. In the case of the disbursement process, the recipient of the planned social assistance in the form of money submits a written request for disbursement to the Mayor through the Regional Apparatus for verification. Each recipient of social assistance is required to complete the following requirements:

a. a letter of application for disbursement signed by the recipient or by an authorized official;

b. plans for the use of social assistance or RAB;

c. photocopy of Electronic Identity Card in the name of the beneficiary or heir;

d. photocopy of bank account that is still active in the name of the beneficiary or heir;

e. a stamped receipt signed and the full name of the recipient included;

f. payment minutes;

g. a stamped integrity pact and signed by the recipient, that the social assistance will be used properly, in accordance with the request;

h. cover letter from local RT/RW/Kelurahan;

i. certificate of heir, if the name of the beneficiary specified in the mayor's decision dies;

j. in the event that the applicant for social assistance is a non-governmental organization (foundation) must also attach a domicile certificate from the kelurahan known to the local sub-district head.

All of these requirements serve as a reference for the Head of Regional Apparatus to verify and make a Minutes of Verification Results which is then submitted to the Head of SKPKD as 
PPKD. In addition to the official report of the verification results, the Regional Apparatus must also attach the following additional requirements:

a. the applicant's initial proposal and the mayor's disposition;

b. minutes of evaluation results;

c. recommendations of the relevant Regional Apparatus;

d. minutes of verification results;

e. a statement letter from the related Regional Apparatus Verification Team, complete with photos of the survey results;

f. a statement of absolute responsibility of the Head of the relevant Regional Apparatus for the results of the verification;

g. stamped receipt;

h. minutes of payment with stamp duty; and a letter of application for issuance and a letter of order to pay.

After all the requirements are declared complete, the head of the SKPKD as PPKD instructs the authorized official to issue a payment request letter, a payment order and a fund disbursement order. Funds that are approved for disbursement will be delivered in the form of a transfer or bookentry from the Regional General Treasury account to the account of the recipient of social assistance.

Supporting factors:

1. There is a regional budget for persons with disabilities.

2. There is South Tangerang Mayor Regulation Number 26 of 2018 concerning Guidelines for the Management of Grants and Social Assistance sourced from the Regional Budget. Obstacle factor:

1. There are no SOPs.

2. Human Resources and Inadequate Infrastructure.

3. No communication (one way only).

According to research conducted by Irsan Akhmad in JIPP entitled Implementation of policies regarding persons with disabilities at the Wisma Cashier Foundation and Panti Sosial Bina Daksa Budi Bhakti Jakarta, the results of the research he conducted explained that the implementation of the Minister of Social Affairs Regulation No. 7 of 2017 has been going well. 


\section{CONCLUSIONS}

Based on the results of the study, it can be concluded that the implementation of the Regional Budget Social Assistance Policy for Disabilities in South Tangerang has not gone well, it is based on communication that does not go well from the implementor to the community, in terms of resources, both human and financial resources are still very lacking, as well as supporting infrastructure in the implementation of social assistance for persons with disabilities. And most importantly, there is no Standard Operational Procedure (SOP) which should be a reference in the implementation of this social assistance program.

\section{REFERENCES}

Ansell, C., Sørensen, E., \& Torfing, J. (2017). Improving policy implementation through collaborative policymaking. Policy and Politics, 45(3), 467-486. https://doi.org/10.1332/030557317X14972799760260

Creswell, JW (2014). A Concise Introduction to Mixed Methods Research. California: SAGE. Damayanti, I. (2018). Granting Based on Bali Governor Regulation Number 2 of 2017 concerning Guidelines for Grants and Social Assistance. Acta Comitas, 3(2), 373. https://doi.org/10.24843/AC.2018.v03.i02.p13

Edwards, GC (1980). Implementing Public Policy. Wangshiton: Congressional Quarterly Inc.

Febtiasari, A. (2017). Grant Management Policy Implementation at the Regional Financial and Asset Management Agency of Central Sulawesi Province. 8.

Fischer, F., Miller, Gerald. J., \& Sidney, Mara. S. (2007). Handbook of Public Policy Analysis (Theory, Politics and Methods). CRC Press.

Gauthier, C., \& Moran, EF (2018). Public policy implementation and basic sanitation issues associated with hydroelectric projects in the Brazilian Amazon: Altamira and the Belo Monte dam. Geoforum, 97, 10-21. https://doi.org/10.1016/j.geoforum.2018.10.001

Miles, BM, \& Huberman, Michael. A. (2009). Qualitative Data Analysis (1st ed.). UI Press.

Mustanir, A. (2016). Implementation of Village Fund Policy and Community Participation in Development in Teteaji Village, Tellu Limpoe District, Sidenreng Rappang Regency. 14.

Nicholson-Crotty, S., \& Carley, S. (2016). Effectiveness, Implementation, and Policy Diffusion: Or “Can We Make That Work for Us?” State Politics \& Policy Quarterly, 16(1), 78-97. https://doi.org/10.1177/1532440015588764

Paranoan, D., \& Djumlani, A. (2017). Implementation of the Village Fund Allocation (Add) Policy in Balansiku Village, Sebatik District, Nunukan Regency. 2, 14. 
South Tangerang Mayor Regulation No.26 of 2018 concerning Guidelines for the Management of Grants and Social Assistance Sourced from APBD. (nd). South Tangerang Mayor Regulation.

Pülzl, H., \& Treib, O. (2017). Implementing public policy. In Handbook of Public Policy Analysis: Theory, Politics, and Methods (pp. 89-108). Taylor and Francis. https://doi.org/10.4324/9781315093192-14

Robichau, RW, \& Lynn, LE (2009). The implementation of public policy: Still the missing link. Policy Studies Journal, 37(1), 21-36. https://doi.org/10.1111/j.1541-0072.2008.00293.x

Rossouw, N., \& Wiseman, K. (2004). Learning from the implementation of environmental public policy instruments after the first ten years of democracy in South Africa. Impact Assessment and Project Appraisal, 22(2), 131-140. https://doi.org/10.3152/147154604781766012

Sætren, H., \& Hupe, PL (2017). Policy implementation in an age of governance. In The Palgrave Handbook of Public Administration and Management in Europe (pp. 553-575). Palgrave Macmillan. https://doi.org/10.1057/978-1-137-55269-3_29

Trisnawati, N. (2016). Implementation of Policy on Distribution of Grants and Social Assistance in the National Unity and Political Agency of Bontang City. Journal of Paradigms, Vol. 5 No. 1.

Van Meter, DS, \& Van Horn, CE (1975). The Policy Implementation Process: A Conceptual Framework. Administration \& Society, 6(4), 445-488. https://doi.org/10.1177/009539977500600404

Verdugo, MA, Jenaro, C., Calvo, I., \& Navas, P. (2017). Disability policy implementation from a cross-cultural perspective. Intellectual and Developmental Disabilities, 55(4), 234-246. https://doi.org/10.1352/1934-9556-55.4.234

Vonk Noordegraaf, D., Annema, JA, \& van Wee, B. (2014). Policy implementation lessons from six road pricing cases. Transportation Research Part A: Policy and Practice, 59, 172-191. https://doi.org/10.1016/j.tra.2013.11.003 